\title{
スギ花粉症に対するセルテクト®の臨床効果
}

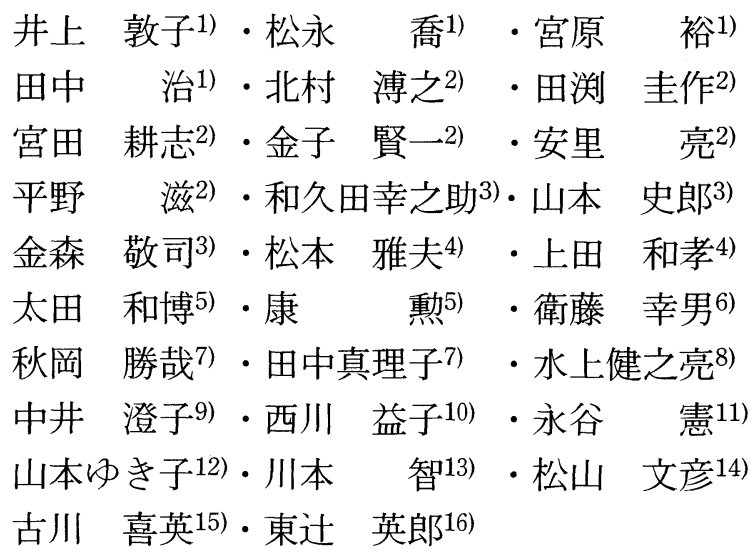

\section{Prophylactic and Therapeutic Efficacy of Oxatomide for Japanese Cedar Pollinosis}

\author{
Atsuko Inoue, Takashi Matsunaga and Hiroshi Miyahara \\ (Nara Medical University), et al
}

The efficacy of oxatomide $\left(\right.$ Celtect $\left.^{\circledR}\right)$, an antiallergic agent, in the treatment of Japanese cedar pollinosis was evaluated in this study of 138 patients, 90 of whom received it prophylactically and 48 therapeutically.

There were good clinical results in 51 of the former and in 21 of the latter. Thus, treatment with oxatomide, either prophylactically or therapeutically appears to be beneficial in the clinical control of pollinosis. The prophylactic and therapeutic effects could not be compared adequately, since the criteria for their evaluation differed. The prophylactic effectiveness was evident throughout the pollen season, while the therapeutic effectiveness was greatest during the middle and late periods of the season.

Key words: Japanese cedar pollinosis, oxatomide, prophylactic effect, therapeutic effect

\footnotetext{
1）奈良県立医科大学耳鼻咽喉科学教室

3）奈良県立奈良病院耳鼻咽喉科

5）奈良県立三室病院耳鼻咽喉科

7）榛原総合病院耳鼻咽喉科

9）中井耳鼻咽喉科医院 (奈良市)

11）永谷耳鼻咽喉科医院 (奈良市)

13）川本耳鼻咽喉科医院 (大和郡山市)

15）石川耳鼻咽喉科医院 (大和高田市)
}

2) 天理よろづ相談所病院耳鼻咽喉科

4) 天理市立病院耳鼻咽喉科

6）済生会奈良病院耳鼻咽䐅科

8）大和郡山総合病院耳鼻咽喉科

10）西川耳鼻咽喉科医院(奈良市)

12）山本耳鼻咽喉科医院 (生駒市)

14）松山耳鼻咽喉科医院 (檟原市)

16）東辻耳鼻咽喉科医院（大和高田市） 
はじめに

春先にスギ花粉を抗原として発症するスギ花 粉症は, 主に I 型のアレルギー反応によりくし やみ，水様性鼻汁，鼻閉などの症状を起こす鼻 アレルギー疾患のひとつである.

奈良県は，県木として吉野杉が有名で，年度 により花粉飛散量の多少はあるものの，例年， この時期は患者にとって, 日常生活に支障を来 すことが多い。また全国的に，この疾患に罹患 する患者数が増加傾向にあるとの報告1)2) も り, 近年社会的問題になってきている.

本疾患の治療には, 第一に, 可能なかぎり原 因抗原からの回避を図ることが重要であり, 第 二に, 精神面, 身体面ともに健全な生活を心が け，第三として薬物療法を行う。薬物療法には 近年次々と種々の抗アレルギー郕が開発されて いるが，oxatomide (セルテクト ${ }^{\circledR}$ ) は1987年 6 月に発売された抗アレルギー剂のひとつであり， 細胞内 $\mathrm{Ca}$ イオンの増加を抑制することにより ヒスタミンやロイコトリエンなどの化学伝達物 質の遊離を強く抑制し，さらに，すでに遊離さ れた化学伝達物質に対しても強い拮抗作用を示 す3）と言われている．本剤の通年性鼻アレル ギーに対する有用性はすでに二重盲検試験で確 認されているが4)， スギ花粉症に対する効果に ついてはまだ十分検討されていない5)。一般に 速効性ではなく, 効果発現までにある程度の投 与期間が必要と言われる抗アレルギー剂におい ては，発症後投与よりも予防投与の有用性が高 いと考觉らる。

そこで，今回我々は，oxatomideをスギ花粉 症患者に花粉飛散前から投与した群(予防投与) 之花粉飛散後, 発症後に投与した群 (治療投与) に分類し，予防効果扐よび発症後の治療効果な らびに安全性を奈良県に拁ける多施設で検討し たので報告する。

\section{方 法}

\section{1. 対 象}

予防投与の対象は, 原則としてスギ花粉飛散 開始予想時期の 2 週間以前に来院したスギ花粉
症患者(重複抗原を有しても可)で，例年の重症 度が軽症以上とした。 また, 対象選択時の症状 の重症度が軽症または無症状のもので, 原則と して16歳以上とし，年齢13〜66歳，平均 38.6 歳, 男性28名, 女性62名, 計90名であった。治療投 与の対象は, スギ花粉飛散時期に発症し来院し た患者で, 重症度が軽症以上の者とし, 年路 14 $\sim 68$ 歳, 平均 34.6 歳, 男性 16 名, 女性 32 名, 計 48 名であった。

試験にあたり，患者の同意を得た。ただし， 以下の患者は除外した.

（1）効果判定を妨げる程度の鼻疾患 (鼻茸, 肥厚性鼻炎, 急性・慢性鼻炎, 鼻中隔弯曲症, 副鼻腔炎など)の合併症を有する患者.

（2）効果判定に影響を及湆す可能性のある薬 剂で持続使用が避けられない患者(抗ヒスタミ ン剤, Disodium cromoglycate, トラニラスト, ケトチフェン, アゼラスチン, ヒスタミン加 $\gamma$ グロブリン製剤, ステロイド剤, 点鼻剤, 点眼 剤, ローウオルフィア系降圧剤).

（3）重症の喘息，気管支拡張症の患者.

（4）減感作療法中の患者(但し，減感作療法 は開始後半年以上経過し, 維持療法中のものは 除外しない).

（5）妊娠打よびその可能性のある患者. 授乳 中の患者.

（6）眠気を催すことがあるので，危険を伴う 機械の操作に従事する患者.

（7）その他，医師が本試験に組み入れること を不適当と判断した患者.

2 . 施 設

奈良県の16施設の耳鼻咽喉科によった(表 1 ). 3 . 期 間

平成 3 年 1 月から 4 月までの約 4 カ月間.

4. 投与方法

予防投与：スギ花粉飛散開始予想時期以前に 予防的治療を希望して来院したスギ花粉症患者 に対し oxatomideを1日 2 錠，分 2 投与した. 治療投与：スギ花粉飛散時期に発症し来院し た患者に対しoxatomideを 1 日 2 錠，分 2 投 
与した。

5. 観察項目

（1）アレルギー性の診断

スギ花粉飛散時期に例年, 鼻, 眼アレルギー 症状発症の既往歴を有し，皮内反応陽性または RAST スュア 1 以上のものをスギ花粉症患者 とした。

（2）鼻症状の程度 $\cdot$ 鼻所見・眼症状

鼻症状の程度 (くしゃ久発作, 鼻汁, 鼻閉, 日常生活の支障度) 拈よびその重症度, 鼻所見 （鼻粘膜腫脹，鼻粘膜色調，鼻汁量，鼻汁の性 状), 眼症状 (かゆみ, 流涙, 充血) は奥田の分 類6)を参考にして記入した。

（3）副作用

問診, 視診などにより担当医師が認めた副作 用について，全てその種類，程度，発現日，消 失日，処置，経過， oxatomide との因果関係な どを調査し，詳細を記載した。

（4）一般臨床検査

本剂投与開始前および投与終了時の計 2 回,

下記の検査をでさるだけ実施し，異常值が認め られた場合は，さらに追跡調査を実施した。 血液検査: 赤血球数, 白血球数, 白血球分類, へモグロビン，へマトクリット，血小板.

肝機能 : GOT, GPT, AL-P.

腎機能 : BUN，クレアチニン.

尿検査：蛋白，糖，ウロビリノーダン，潜血.

（5）oxatomide 服用状況

鼻アレルギー日記より, 来院時毎に総服用量
を臨床調査票に記入した。

（6）患者背景

予防投与，治療投与とも年齢，性別，合併症， 重複抗原, アトピー性疾患既往歴, アレルギー 家族歴, 皮内反応, RAST スコア(スギ), 発 病年齢，罹病期間，前年の症状，前年の重症度， 前年の病型につき調査した。

6. スギ花粉空中飛散量測定

スギ花粉空中飛散量は Durham 法 (Durham 型花粉捕集器を設置しワセリンを塗布したスラ イドグラスを24時間放置して捕集する)にて得 た標本を Calberla 液で染色後鏡検し, $1 \mathrm{~cm}^{2}$ 当 たりの花粉数を算定して測定值とした．毎日測 定記録した結果，飛散量は各地で異なっていた が，今回は代表として奈良県中央に位置する奈 良県立医科大学での測定値のみを示した(図 1 ).

7 . 併用療法, 併用薬剤

oxatomide 投与期間中は，原則として併用療 法，併用薬剤の投与は行わないことにした。亦 た，原則として市販の点鼻薬，点眼薬の使用も 避けることとした。ただし，症状が激しく止む を得ない場合，抗ヒスタミン剂(タベジール®)， ステロイド剂(セレスタミン®)の頓用，抗アレ ルギー剤 (インタール®)の点眼, 血管収縮剤 (コールタイジン $\left.{ }^{\mathbb{B}}\right)$ の点鼻を行った. 併用の際 は, 薬剂名, 使用法, 使用量, 投与期間等を記 載した。

8. 効果判定

(1) 症状別効果判定では, 奥田の分類 $\left.{ }^{6}\right)$ (鼻

表 1 参加施設
1 ）奈良県立医科大学耳鼻咽喉科学教室
9 ）中井耳鼻咽喉科医院
2 ) 天理よろづ相談所病院耳鼻咽喉科
10）西川耳鼻咽喉科医院
3 ）奈良県立奈良病院耳鼻咽喉科
11）永谷耳鼻咽喉科医院
4 ) 天理市立病院耳鼻咽喉科
12）山本耳鼻咽喉科医院
5 ) 奈良県立三室病院耳鼻咽喉科
13）川本耳鼻咽喉科医院
6 ）済生会奈良病院耳鼻咽喉科
14）松山耳鼻咽喉科医院
7 ）榛原総合病院耳鼻咽喉科
15）石川耳鼻咽喉科医院
8 ）大和郡山総合病院耳鼻咽喉科
16）東辻耳鼻咽喉科医院 
症状の重症度 - 程度分類, 鼻所見・眼症状分類) に従い，oxatomide 投与前の所見を対照とし， oxatomide 投与時の鼻症状, 鼻所見, 眼症状の 推移を観察して，本薬剤の臨床効果を評価した。 予防投与では表 2 を参考に 4 段階, 治療投与で は表 3 を参考に 5 段階に効果判定した.

（2）有効性判定は，予防投与では，飛散中期 および飛散後期の全般的改善の各症状, 鼻所見

表 2 予防効果判定法

\begin{tabular}{|l|l|l|}
\hline \multicolumn{2}{|l|}{} & \multicolumn{2}{|c|}{ 症度の変化 } \\
\hline 1 & 著明な効果あり & 不 変 \\
\hline 2 & 中等度の効果あり & 1 段階悪化 \\
\hline 3 & 軽度の効果あり & 2 段階悪化 \\
\hline 4 & 効 果 な し & 3 段階悪化 \\
\hline
\end{tabular}

を，治療投与では，投与 2 週後および 4 週後, 全般的改善の各症状，鼻所見を考慮して，下記 の 4 段階で判定した.

1 : 著明な効果あり 2 : 中等度の効果あり

3 : 軽度の効果あり 4 : 効果なし

（3）安全性は，副作用および臨床検査異常の 程度により安全性を下記の 4 段階で判定した.

1 : 問題なし 2 : やや問題あり

3 : 問題あり

$4:$ 極めて問題あり（投与中止）

（4）有用性は，有効性，安全性拉よび担当医 の印象を加味して下記の 5 段階で判定した.

1 : 極めて有用 2 : 有用 3 : やや有用 4:有用でない 5 : 有害

表 3 治療効果判定法

\begin{tabular}{|c|c|c|c|}
\hline & & & 段 階 的 な 差 \\
\hline \multirow{2}{*}{$\begin{array}{l}\text { 症 } \\
\text { 状 } \\
\text { 別 }\end{array}$} & 1 & 消 失 & $H \rightarrow-$ - $\# \rightarrow-$ - $+\rightarrow-$ \\
\hline & 2 & 著明改普 & $\mathrm{H} \rightarrow+$ \\
\hline 効 & 3 & 並 & $H \rightarrow H 、 H \rightarrow+$ \\
\hline 米 & 4 & 不 変 & $H \rightarrow H 、 H \rightarrow H 、+\rightarrow+$ \\
\hline 定 & 5 & 悪 化 & $-\rightarrow+,-\rightarrow H 、-\rightarrow$ m、 $+\rightarrow H 、+\rightarrow$ m、H $\rightarrow$ m \\
\hline
\end{tabular}

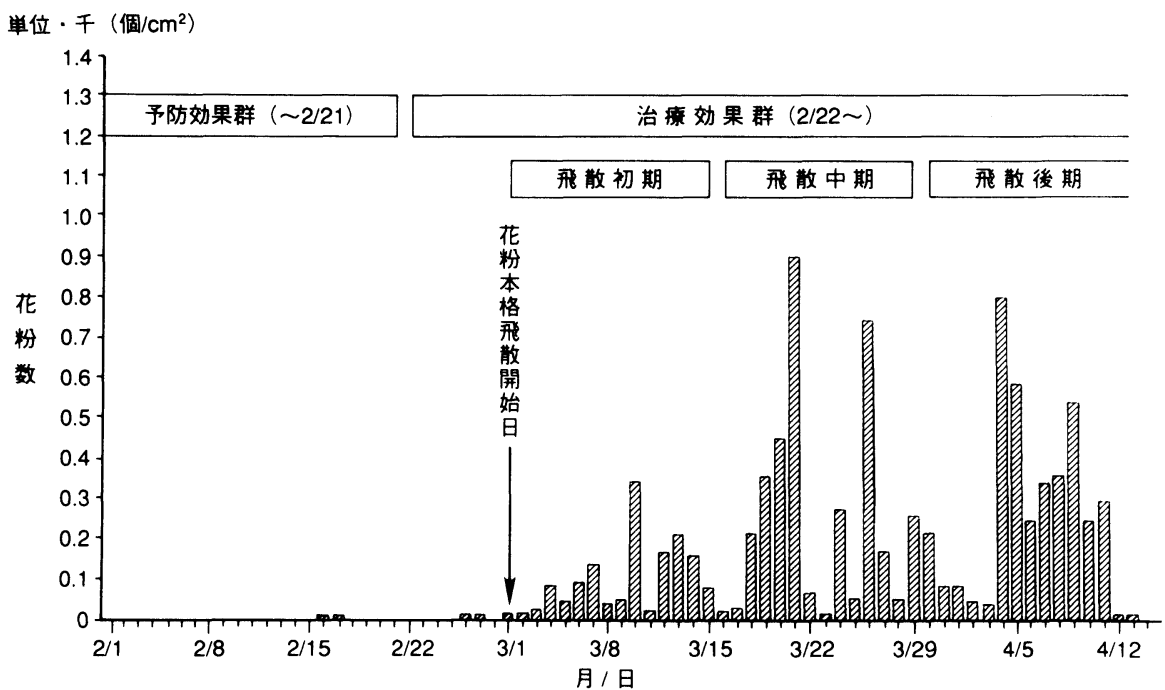

図 1 平成 3 年度スギ花粉飛散数(奈良県立医科大学) 
9. スギ花粉症効果判定分割日

oxatomide の予防効果として，理想的には 2 週間必要と考えられるが，1 週間あれば予防効 果がみられると考光，3月1日の花粉本格的飛 散開始日より， 1 週間以前の 2 月 22 日を境に予 防投与と治療投与に分けた。また，3月15日ま でを飛散初期，3 月29日までを飛散中期，それ 以降を飛散後期とした。

\section{結果}

\section{1. スギ花粉飛散数}

平成 3 年 2 月から 4 月までの約 3 カ月間のス ギ花粉飛散状況を図 1 に示す。花粉は，2 月 16 日から飛散が認められたが, 低温等, 天候不順 のため, その後飛散は停滞し，3 月に入ってス ギ花粉数の増加が認められた。

そこで今回， 3 月 1 日の 6 個 $/ \mathrm{cm}^{2}$ を花粉本 格飛散開始日とし，3 月10日を飛散第一ピーク $\left(337\right.$ 個 $\left./ \mathrm{cm}^{2}\right) ， 3$ 月21日 $\left(900\right.$ 個 $\left./ \mathrm{cm}^{2}\right), 3$ 月 26 日 $\left(735\right.$ 個 $\left./ \mathrm{cm}^{2}\right), 4$ 月 4 日 $\left(793\right.$ 個 $\left./ \mathrm{cm}^{2}\right)$ を本シー

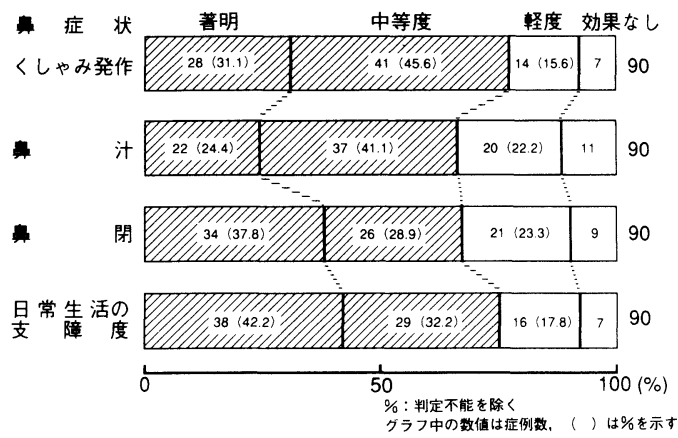

図 2 予防効果 (鼻症状)

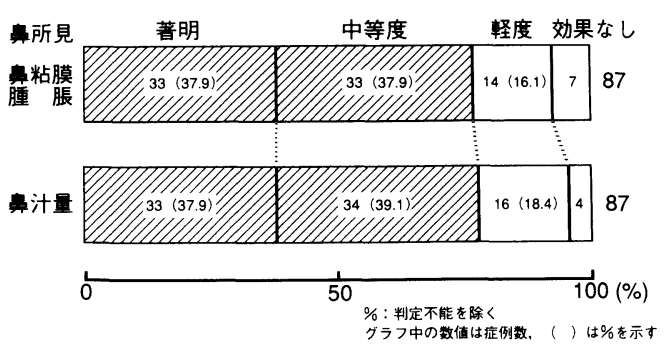

図 3 予防効果(鼻所見)
ズンにおける飛散数のピークとし，3月15日ま でを飛散初期，3月29日までを飛散中期，それ 以降を飛散後期とした（図 1 ).

2. 全般的改善抢よび各症状に対する効果

(1) 予防投与

鼻症状では，特にくしゃみ発作に効果が高く， 中等度以上の改善率は76.7\%で，鼻汁では 65.6 $\%$ ，鼻閉では66.7\%の改善率を示した(図 2 ). また鼻所見では鼻粘膜腫脹 $75.9 \%$, 鼻汁量 77.0 $\%$ と, 高い改善率を得た(図 3 ).

（2）治療投与

鼻症状では, 鼻汁に最も良い効果がみられ, 中等度以上の改善率は $65.2 \%$ で，〈しpみ発作 は $60.9 \%$ ，鼻閉は $59.5 \%$ の改善率を示した (図 4 )。また, 鼻所見では, 鼻粘膜腫脹 $37.6 \%$, 鼻汁量 $44.2 \%$ であった(図 5 ).

(3) 症状 - 所見別, 時期別重症度

症状の効果判定法は，予防投与と治療投与で 異なり，この両者を直接比較することは難しい．

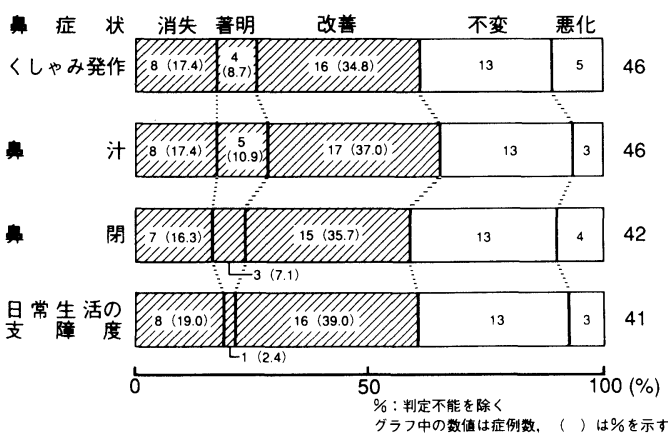

図 4 治療効果 (鼻症状)

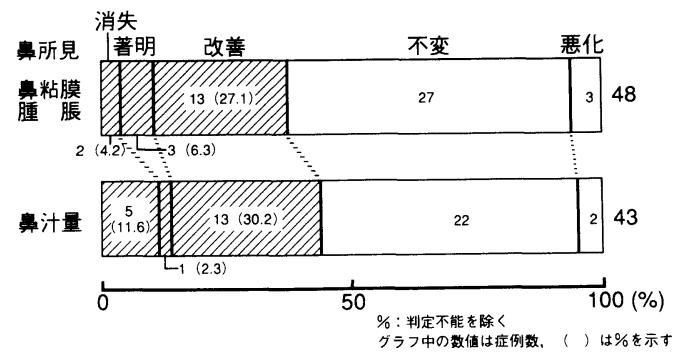

図 5 治療効果(鼻所見) 
そこで今回，1 週間単位の受診日別に分け，そ の時点での患者の症状を予防投与と治療投与に ついて比較検討してみた. 図 $6 \sim 9$ の平均スコ アは, 0 : 無症状, 1 : 軽症, 2 : 中等症, 3 : 重症，としたものの平均値を示した。

(1) くしゃみ発作

図 6 亿示すように，花粉飛散初期に予防投与 群に有意な症状の軽減が認められた。また，飛 散中期, 後期に括いては, 両群とも有意差はな いものの症状の軽減が認められた。

(2)鼻 汁

図 7 に示すように，予防投与は花粉飛散初期 から 3 月中旬に扮いて，治療投与より有意な症 状の軽減が認められた。また，飛散中期，後期 では両群とも症状の軽減がみられた。

(3)鼻 閉

図 8 亿示すよ5に，飛散初期から 3 月中旬文 で予防投与に有意な症状軽減が認められ，飛散 後期には両者に差はみられなかった。

(4)日常生活の支障度

図 9 に示寸ように，飛散初期から 3 月中旬ま で予防投与に有意な症状の軽減があり，それ以
降両者に差はみられなかった。

(5)鼻所見

鼻粘膜腫脹, 鼻汁量とも, 鼻症状と同様の結 果であった。

3 . 有効性

予防投与 : 飛散中期では, 中等度以上の改善 率は $56.7 \%$, 飛散後期では $65.0 \%$, 全般的改善 では60.0\%であった(表 4 )。

治療投与: 投与 2 週後では, 中等度以上の改 善率は $39.6 \%$, 投与 4 週後では $48.8 \%$, 全般的 改善では47.7\%であった(表 5 ).

4. 患者背景別有効性

患者背景別に有効率をみると，中等度改善以 上 $\left(\chi^{2}\right.$ 検定 - Fisher の検定, $\mathrm{p}<0.05$ の危険率 $)$ にて有意差のみられた項目は，予防投与・飛散 中期の判定で，アトピー性疾患既往歴のない症 例がある症例に対して有効性が高く，前年の重 症度に执いても中等症十軽症が重症に比較して 高く, 前年の病型では, くしゃ久鼻汁型が鼻閉 型十くしゃ及鼻閉型より有効性が高かった （表 6 ). 治療投与・投与 4 週後の検討では，前 年の重症度にて, 重症が中等症十軽症に比較し

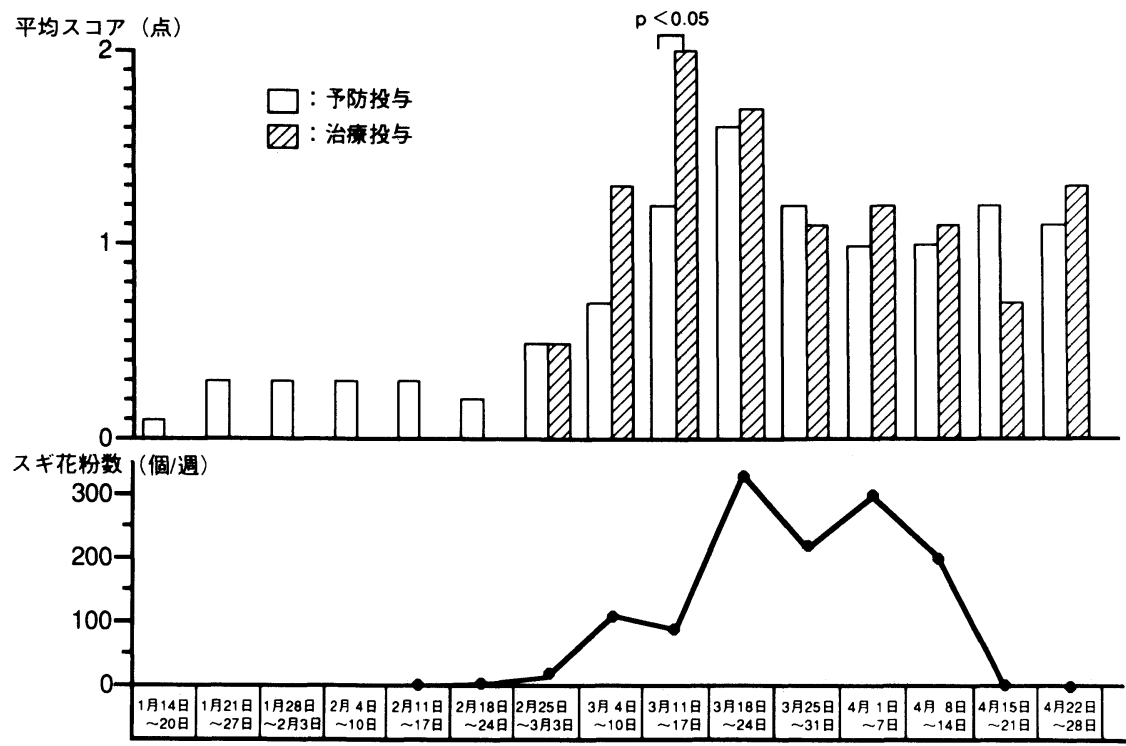

図 6 くしゃ文発作 
て有効性が高かった（表 7 ). 予防投与・飛散後 期，予防投与 - 全般的判定，治療投与 - 投与 2 週後, 治療投与 - 全般的改善には, 患者背景別 解析に执いて統計的な差はなかった。また，併
用薬剤の有無では, 全体的な傾向として, 併用 薬剤ありよりなしの活らが有用性が高かった。 5 . 安全性拉よび副作用, 有用性

予防投与 : 飛散中期では90例中, 問題あり,

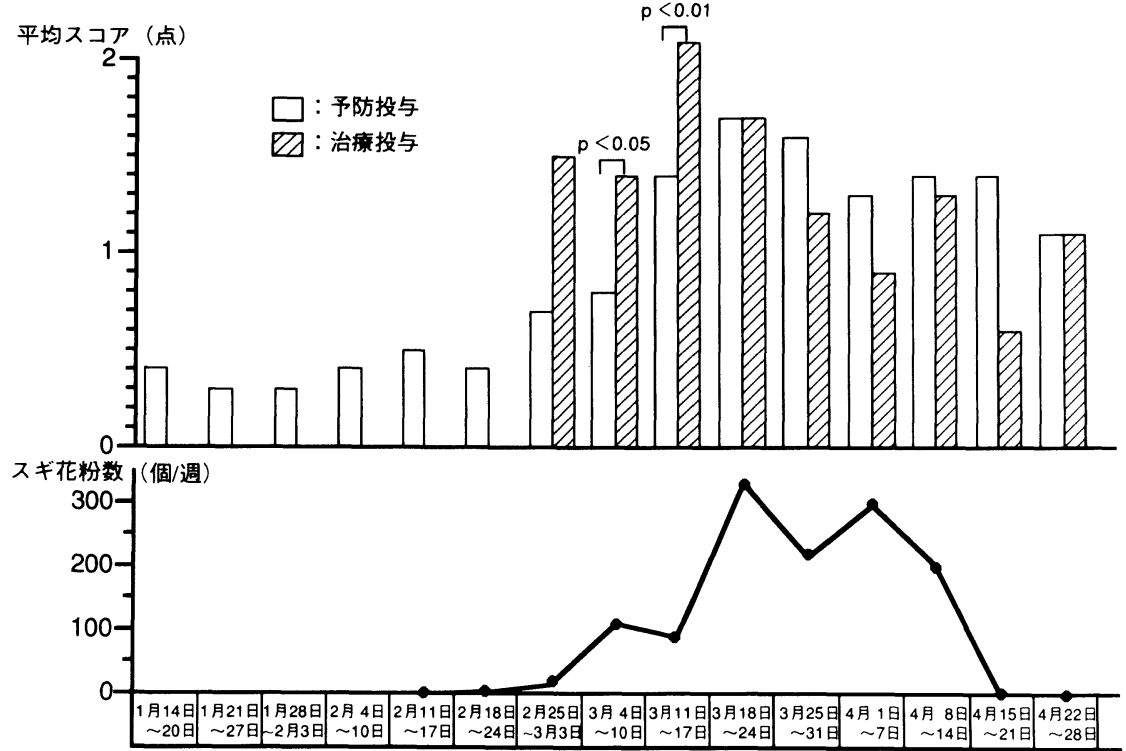

図 7 鼻 汁

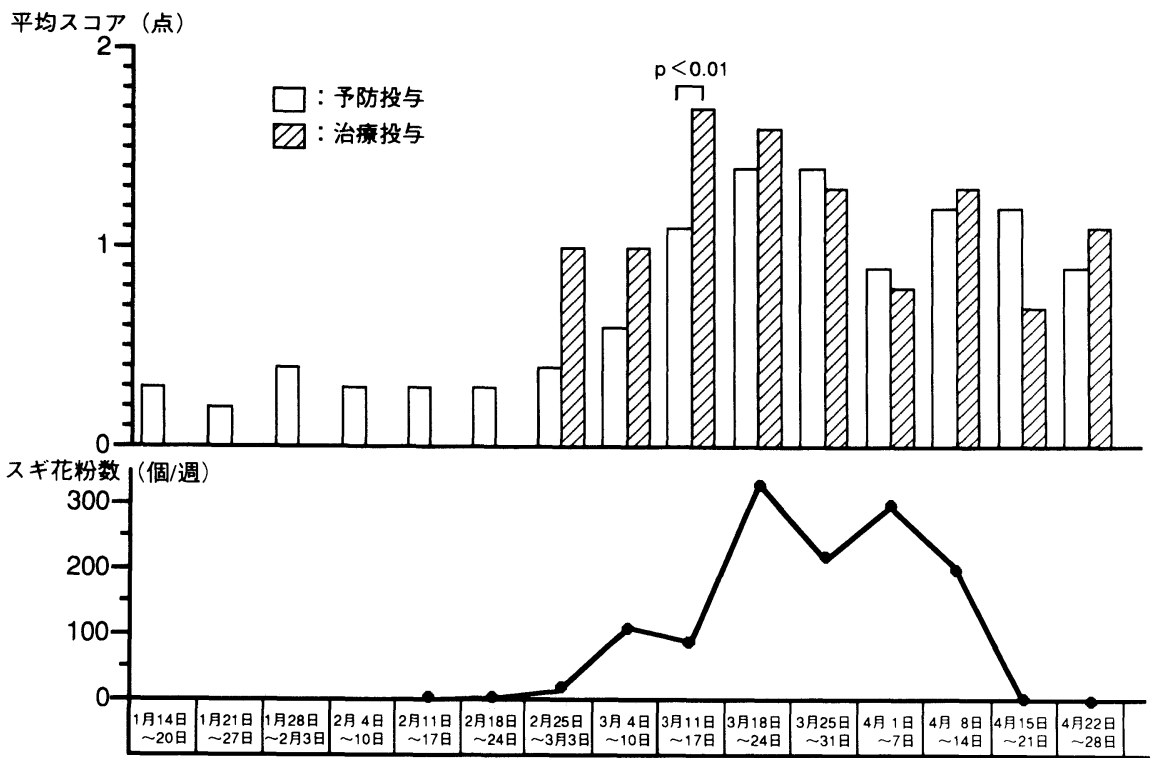

図 8 鼻 閉 
やや問題ありと判定された患者は 1 例ずつみら れたが，いずれも軽度の眠気のためであり，極 めて問題ありと判定されたものはみられなかっ た、全般的判定では，問題なしと判定されたも のが90例中 87 例で， $98.9 \%$ であり，有用以上と
判定されたものは56.3\%であった(表 4 )。副作 用発現率は，90例中 1 例で1.1\%であった。

治療投与: 投与 2 週後, 投与 4 週後, 全般的 改善とも, やや問題ありと判定されたものは42 例中 2 例で，副作用発現率は $4.5 \%$ であり，や

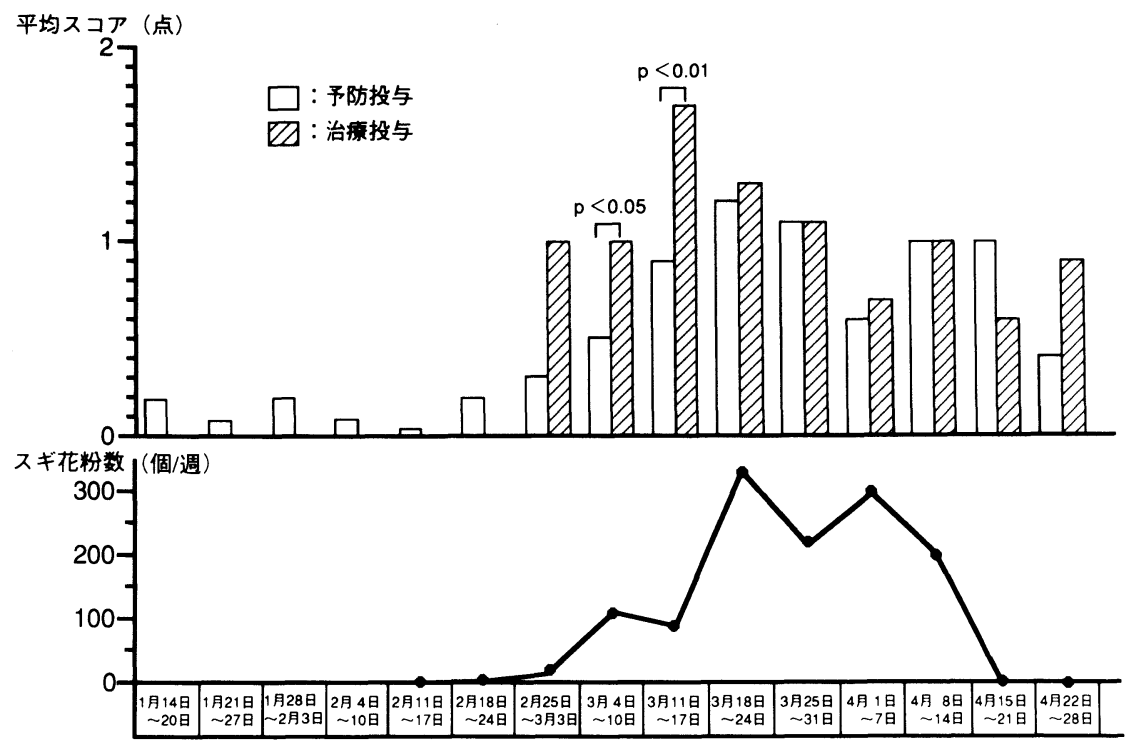

図 9 日常生活の支障度

表 4 最終総合評価(予防投与)

\begin{tabular}{|c|c|c|c|c|c|c|}
\hline 有効 & 著明な効果あり & 中等度の奻果あり & 軽度の効果あり & 奻 & し & \\
\hline 飛散中期 $\quad(n=90)$ & $\begin{array}{c}11 \\
(12.2 \%)\end{array}$ & $\begin{array}{c}40 \\
(44.5 \%)\end{array}$ & $\begin{array}{c}29 \\
(32.2 \%)\end{array}$ & \multicolumn{3}{|c|}{$\begin{array}{c}10 \\
(11.1 \%)\end{array}$} \\
\hline 飛散後期 $\quad(n=80)$ & $\begin{array}{c}13 \\
(16.3 \%)\end{array}$ & $\begin{array}{c}39 \\
(48.8 \%)\end{array}$ & $\begin{array}{c}21 \\
(26.3 \%)\end{array}$ & \multicolumn{3}{|c|}{$\begin{array}{c}7 \\
(8.8 \%)\end{array}$} \\
\hline 全般的改善（ $n=85 ）$ & $\begin{array}{c}12 \\
(14.1 \%)\end{array}$ & $\begin{array}{c}39 \\
(45.9 \%)\end{array}$ & $\begin{array}{c}30 \\
(35.3 \%)\end{array}$ & \multicolumn{3}{|c|}{$\begin{array}{c}4 \\
(4.7 \%)\end{array}$} \\
\hline 概 括 安 全 度 & 問題なし & やや問題あり & 問題あり & \multicolumn{3}{|c|}{ 極めて問題あり } \\
\hline 飛散中期 $\quad(n=90)$ & $\begin{array}{c}88 \\
(97.8 \%)\end{array}$ & $\left(\begin{array}{c}1 \\
(1.1 \%)\end{array}\right.$ & $\left(\begin{array}{c}1 \\
(1.1 \%)\end{array}\right.$ & \multicolumn{3}{|c|}{0} \\
\hline 飛散後期 $\quad(n=83)$ & $\begin{array}{c}82 \\
(98.8 \%)\end{array}$ & 0 & $(1.2 \%)$ & \multicolumn{3}{|c|}{0} \\
\hline 全般的改善（ $n=88 ）$ & $\begin{array}{c}87 \\
(98.9 \%)\end{array}$ & 0 & $\left(\begin{array}{c}1 \\
(1.1 \%)\end{array}\right.$ & \multicolumn{3}{|c|}{0} \\
\hline 有 用 & 極めて有用 & 有 用 & やや有用 & 有用でない & 有 & \\
\hline 飛散中期 $\quad(n=90)$ & $\begin{array}{c}10 \\
(11.1 \%)\end{array}$ & $\begin{array}{c}37 \\
(41.1 \%)\end{array}$ & $\begin{array}{c}34 \\
(37.8 \%)\end{array}$ & $\stackrel{9}{9}(10.0 \%)$ & & 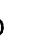 \\
\hline 飛散後期 $\quad(n=82)$ & $\begin{array}{c}12 \\
(14.6 \%)\end{array}$ & $\begin{array}{c}36 \\
(43.9 \%)\end{array}$ & $\begin{array}{c}25 \\
(30.5 \%)\end{array}$ & $\stackrel{9}{(11.0 \%)}$ & & 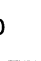 \\
\hline 全般的改善（ $n=87 ）$ & $\begin{array}{c}11 \\
(12.6 \%)\end{array}$ & $\begin{array}{c}38 \\
(43.7 \%)\end{array}$ & $\begin{array}{c}33 \\
(37.9 \%)\end{array}$ & $\begin{array}{c}5 \\
(5.7 \%)\end{array}$ & & 0 \\
\hline
\end{tabular}


はり軽度の眠気のためであった。 また, 全般改 善度で問題なしと判定されたものは42例で 95.5 \%であり，有用以上と判定されたものは $45.5 \%$ であった(表 5 )。

\section{考察}

スギ花粉症は，通年性鼻アレルギーに比較し て，主に 2 月から 4 月といら短期間の発症であ るが，患者にとっては日常生活に支障を来し，

表 5 最終総合評価(治療投与)

\begin{tabular}{|c|c|c|c|c|c|c|}
\hline 有 奻 & 著明な奻果あり & 中等度の奻果あり & 軽度の効果あり & 奻 & な & \\
\hline 投与 2 週後 $\quad(n=48)$ & $\begin{array}{c}7 \\
(14.6 \%)\end{array}$ & $\begin{array}{c}12 \\
(25.0 \%)\end{array}$ & $\begin{array}{c}15 \\
(31.2 \%)\end{array}$ & \multicolumn{3}{|c|}{$\begin{array}{c}14 \\
(29.2 \%)\end{array}$} \\
\hline 投与 4 週後 $\quad(n=41)$ & $\begin{array}{c}7 \\
(17.1 \%)\end{array}$ & $\begin{array}{c}13 \\
(31.7 \%)\end{array}$ & $\begin{array}{c}15 \\
(36.6 \%)\end{array}$ & \multicolumn{3}{|c|}{$\begin{array}{c}6 \\
(14.6 \%)\end{array}$} \\
\hline 全般的改善 $\quad(n=42)$ & $\begin{array}{l}7 \\
(16.6 \%)\end{array}$ & $\begin{array}{c}14 \\
(33.3 \%)\end{array}$ & $\begin{array}{c}17 \\
(40.4 \%)\end{array}$ & \multicolumn{3}{|c|}{$\begin{array}{c}4 \\
(9.5 \%)\end{array}$} \\
\hline 概 括 安 全 度 & 問題なし & やや問題あり & 問題あり & \multicolumn{3}{|c|}{ 極めて問題あり } \\
\hline 投与 2 週後 $\quad(n=48)$ & $\begin{array}{c}46 \\
(95.8 \%)\end{array}$ & $\stackrel{2}{(4.2 \%)}$ & 0 & \multicolumn{3}{|c|}{0} \\
\hline 投与 4 週後 $\quad(n=41)$ & $\begin{array}{c}39 \\
(95.1 \%)\end{array}$ & $\begin{array}{l}2 \\
(4.9 \%)\end{array}$ & 0 & \multicolumn{3}{|c|}{0} \\
\hline 全般的改善 $\quad(n=44)$ & $\begin{array}{c}42 \\
(95.5 \%)\end{array}$ & $\begin{array}{c}2 \\
(4.5 \%)\end{array}$ & 0 & \multicolumn{3}{|c|}{0} \\
\hline 有用 & 極めて有用 & 有 用 & やや有用 & 有用でない & 有 & 害 \\
\hline 投与 2 週後 & $\begin{array}{c}7 \\
(14.6 \%)\end{array}$ & $\begin{array}{c}10 \\
(20.8 \%)\end{array}$ & $\begin{array}{c}17 \\
(35.4 \%)\end{array}$ & $\begin{array}{c}14 \\
(29.8 \%)\end{array}$ & & 0 \\
\hline 投与 4 週後 $\quad(n=41)$ & $\begin{array}{c}6 \\
(14.6 \%)\end{array}$ & $\begin{array}{c}12 \\
(29.3 \%)\end{array}$ & $\begin{array}{c}18 \\
(43.9 \%)\end{array}$ & $\begin{array}{c}5 \\
(12.2 \%)\end{array}$ & & 0 \\
\hline 全般的改善 $\quad(n=44)$ & $\begin{array}{c}5 \\
(11.4 \%)\end{array}$ & $\begin{array}{c}15 \\
(34.1 \%)\end{array}$ & $\begin{array}{c}19 \\
(43.2 \%)\end{array}$ & $\begin{array}{c}5 \\
(11.4 \%)\end{array}$ & & 0 \\
\hline
\end{tabular}

表 6 患者背景別有効性 (予防投与 - 飛散中期)

\begin{tabular}{|c|c|c|c|c|c|c|c|c|c|}
\hline \multirow{2}{*}{ 項 目 } & \multirow{2}{*}{ 分 類 } & \multicolumn{4}{|c|}{ 有 効 性 } & \multirow{2}{*}{ 計 } & \multirow{2}{*}{$\begin{array}{c}\text { 中等度 } \\
\text { 以上 }\end{array}$} & \multirow{2}{*}{$\%$} & \multirow{2}{*}{$\begin{array}{l}\chi^{2} \text { 検定 } \cdot \text { Fisher } \\
\text { (中等度改善以上) }\end{array}$} \\
\hline & & 著 明 & 中等度 & 軽 度 & 効果なし & & & & \\
\hline \multirow{2}{*}{$\begin{array}{l}\text { アトピー性 } \\
\text { 疾患既往歴 }\end{array}$} & な し & 11 & 39 & 22 & 9 & 81 & 50 & 61.7 & \multirow{2}{*}{ なし>あり** } \\
\hline & あ り & 0 & 1 & 7 & 1 & 9 & 1 & 11.1 & \\
\hline \multirow{4}{*}{$\begin{array}{l}\text { 前年の } \\
\text { 重症度 }\end{array}$} & 重 症 & 4 & 7 & 15 & 4 & 30 & 11 & 36.7 & \multirow{3}{*}{ 中等症十軽症 >重症 * } \\
\hline & 中等症 & 6 & 26 & 9 & 4 & 45 & 32 & 71.1 & \\
\hline & 軽 症 & 1 & 4 & 3 & 1 & 9 & 5 & 55.6 & \\
\hline & 不 明 & 0 & 3 & 2 & 1 & 6 & 3 & 50.0 & \\
\hline \multirow{3}{*}{$\begin{array}{l}\text { 前年の } \\
\text { 病 型 }\end{array}$} & $\begin{array}{l}<し ゃ み \\
\text { 汁型 }\end{array}$ & 7 & 27 & 13 & 3 & 50 & 34 & 68.0 & \multirow{3}{*}{$\begin{array}{l}\langle し や み \text { 鼻汁型 }> \\
\text { 鼻閉型+くしゃみ鼻閉型” }\end{array}$} \\
\hline & 閉型 & 1 & 4 & 2 & 2 & 9 & 5 & 55.6 & \\
\hline & $\begin{array}{l}\text { くしゃみ } \\
\text { 閉型 }\end{array}$ & 2 & 2 & 6 & 5 & 15 & 4 & 26.7 & \\
\hline
\end{tabular}


大きな社会問題になってきている. 本症の治療 には，抗アレルギー剂と速効性のあるステロイ ド剤, 血管収縮剂, 抗ヒスタミン剂の併用療法 が重要視されているが，近年，一般に作用の発 現がゆるやかである抗アレルギー剂を花粉飛散 前から予防的に投与すると有用性が高いと言わ れており，ケトチフェン7)，トラニラスト8) 10) でこのような効果がすでに報告されている.こ れらの報告によれば，飛散開始の $1 \sim 2$ 週間前 から薬剂を投与することによって，飛散後の投 与よりも有意に高い効果が得られている.

平成 3 年は, 奈良県では, 予想通りかなり多 くの飛散が観察された. 今回の検討では, 症状 の効果判定法は, 予防投与と治療投与で異なり, この両者を直接比較することは難しいため, 同 じ時期の 1 週間単位の受診日別に分け，その時 点での患者の症状を予防投与と治療投与につい て比較検討してみると，予防投与，治療投与と も，3月10日の飛散第一ピーク $\left(337\right.$ 個 $\left./ \mathrm{cm}^{2}\right)$ を 迎光た際, 症状の急激な増悪をみているものの, その後 3 月 21 日 $\left(900\right.$ 個 $\left./ \mathrm{cm}^{2}\right), 3$ 月26日 (735個 $\left./ \mathrm{cm}^{2}\right)$, 4 月 4 日 $\left(793\right.$ 個 $\left./ \mathrm{cm}^{2}\right)$ と, それ以上の ピークを迎えたにもかかわらず，各症状は改善 傾向にある. これは，予防投与，治療投与両方 に拈ける oxatomide の効果によるものと考兄 られた．投与期間にかかわらず，飛散中・後期 には，患者の鼻粘膜は非常に過敏になっており， 少しの刺激でも発作が起こるので, 抗アレル ギー剤による症状の改善は難しいと言われてい
るが11)，今回の結果では，投与期間が長いと oxatomide の効果も維持できると思われた。 ま た, 飛散初期では，予防投与は治療投与に比べ, 第一ピーク期前後の各種鼻症状のスコアが有意 に改善されて括り，oxatomideの予防投与の花 粉飛散初期に括ける有用性が示唆された。

ただし，全般的改善の予防投与の効果判定に 沶いて, 鼻症状, 鼻所見の中等度以上改善率は, すべて $65 \%$ 以上と高率であったが，来院時に無 症状であっても, もともと症状のない患者のう ち, 臨床調査表に前年の鼻症状の記載のないも のは, 無症状が続くと不変と判定され，この場 合症状別効果判定に基づき, 著明改善に含まれ てしまうため, 判定が難しく思われた。これに 対し, 治療投与では, 初診時, 症状のなかった ものは含まれておらず，この判定は客観性が高 いと思われた。

患者背景別有効性のなかで，予防投与で，中 等症十軽症の方が統計的に有意に有効性が高か ったのは，発症を抑制するのは軽症の方が抑制 しやすく, 重症の活らが抑制しにくいため, 中 等症十軽症が重症に比較して有効性が高かった と考觉られた。 また，治療投与・投与 4 週後に 拈ける前年の重症度では, 予防投与の時と逆に, 重症の方が有効性が高かった。 その理由は, 発 症した症状の軽減に掞いて, 軽症の人の症状が なくなることよりも，重症の人が中等症になる 方が主治医の印象がよくなるためと思われた. また，予防投与 - 飛散中期の判定で，アトピー

表 7 患者背景別有効性（治療投与 - 投与 4 週後)

\begin{tabular}{|c|c|c|c|c|c|c|c|c|c|c|}
\hline \multirow{2}{*}{ 項 目 } & \multirow{2}{*}{ 分 類 } & \multicolumn{5}{|c|}{ 有 効 性 } & \multirow{2}{*}{ 計 } & \multirow{2}{*}{$\begin{array}{c}\text { 中等度 } \\
\text { 以上 }\end{array}$} & \multirow{2}{*}{$\%$} & \multirow{2}{*}{$\begin{array}{l}\chi^{2} \text { 検定 } \cdot \text { Fisher } \\
\text { (中等度改善以上) }\end{array}$} \\
\hline & & 著 明 & 中等度 & 軽 度 & 効果なし & 判定不能 & & & & \\
\hline \multirow{3}{*}{$\begin{array}{l}\text { 前年の } \\
\text { 重症度 }\end{array}$} & 重 症 & 3 & 4 & 1 & 0 & 1 & 9 & 7 & 87.5 & \multirow{3}{*}{$\begin{array}{l}\text { 重症> } \\
\text { 中等症十軽症" }\end{array}$} \\
\hline & 中等症 & 2 & 6 & 11 & 4 & 3 & 26 & 8 & 34.8 & \\
\hline & 軽 症 & 0 & 2 & 3 & 2 & 2 & 9 & 2 & 28.6 & \\
\hline
\end{tabular}

$\%:$ 判定不能を除く

* : $p<0.05$ 
性疾患既往歴がない症例がある症例に対して有 効性が高く, これは従来の我々の治療経験や各 種の報告から納得できる結果であった．前年の 病型では, くしゃ及鼻汁型が重症度の高いとさ れる鼻閉型十くしゃ久鼻閉型より有効性が高く, 他の抗アレルギー剂一般の報告と同様の結果が 得られた。 また, 併用薬剤の有無では, 併用薬 剂ありよりなしの注らが効果が高く，これは併 用薬剂ありには重症例が多いことも考兄られる が，併用薬剤なしでも十分な効果が期待できる 症例があると考学られた。

\section{まとめ}

oxatomide のスギ花粉症に対する予防効果並 びに治療効果の検討を平成 3 年に奈良県内の耳 鼻咽喉科16施設で行った.

1. 予防投与 90 名 (男性 28 名, 女性62名)は, 治療投与48名(男性16名, 女性32名)に比べ, 第 一ピーク期前後の各種鼻症状のスコアが有意に 改善されて扣り, oxatomideの予防投与の花粉 飛散初期に括ける有用性が示唆された.

2. 飛散第一ピーク時に増悪した鼻症状も， 飛散中期, 後期に扣いては, 予防投与, 治療投 与ともにいずれも改善傾向にあり, oxatomide の効果によるものと考えられた。

3. 副作用は, 眠気が数例に認められたが, 安全性に問題があるものはなかった。

4. 以上より，スギ花粉症患者に対するセル テクト ${ }^{\circledR} の$ 有効性は高く, 重篤な副作用もなく 安全性も高いものと考えられた。 また，花粉飛 散前から本剂を投与(予防投与)することにより， 花粉飛散初期の症状覀化を予防し得る可能性も 認められた。

\section{文献}

1）斎藤洋三, 清水章治, 佐橋紀男, 他 : 花粉症疫 学調査の試久 一東京都花粉症対策検討委員会 の調査報告より一. JOHNS $4: 177 \sim 183,1988$.

2）奥田 稔: 鼻アレルギー. 101 126頁, 金原出 版, 東京, 1988 .

3) 大森健守, 石井秀衛, 二藤真明, 他: Oxatomide $の$ 薬理作用一第 7 報：抗 chemical mediator 作用一. 日薬理誌 $81: 399 \sim 409,1983$.

4）奥田 稔, 斎藤洋三, 石井哲夫, 他: スギ花粉 症に対するオキサトミドの予防・治療効果. 耳 展 32 補 $4: 295 \sim 323,1989$.

5) 辻田達朗, 井口郁雄, 西岡出雄, 他: 花粉症に 対するセルテクト ${ }^{\circledR}$ (oxatomide) の予防ならび に治療効果の検討. 診と薬 $26: 89 \sim 96,1989$.

6）奥田 稔: 鼻アレルギー. 266〜274頁, 金原出 版, 東京, 1988 .

7）奥田 稔, 古内一郎, 佐々木好久, 他: スギ花 粉症に対するケトチフェンの季節前投与の予防 効果. 耳展 29 補 $3: 277 \sim 293,1986$.

8）奥田 稔, 矢島 洋, 古内一郎, 他: スギ花粉 症に対するトラニラストの予防効果. 耳展 30 補 $3: 219 \sim 243,1987$.

9）洲崎春海, 野村恭也, 水野正浩, 他 : スギ花粉 症に対するトラニラストの効果 一関東地区多 施設 open trial の結果一. 耳展 34 補 $7: 575 \sim$ 581, 1991.

10）新川 敦, 三宅浩郷, 石塚洋一, 他: スギ花粉 症に対するトラニラストの効果 一神奈川県多 施設による 3 年間の検討一。耳鼻臨床 85 ： 1855 1864, 1992.

11）大橋伸一, 山崎 太, 森岡 保: スギ花粉症に 対するトラニラスト使用経験 一予防的治療効 果について一. 耳展 30 補 $3: 245 \sim 253,1987$.

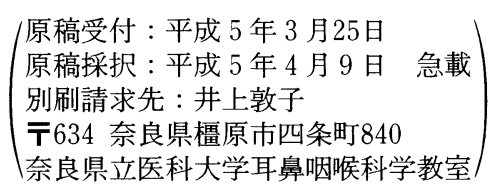

